\title{
Literasi Digital Dalam Membentuk Karakter Religius Generasi Milenial (Studi tentang Pembentukan Karakter Mahasiswa PAI Universitas Muhammadiyah Gresik)
}

\author{
Noor Amirudin \\ Universitas Muhammadiyah Gresik, Indonesia \\ E-Mail: amir@umg.ac.id
}

\begin{abstract}
The current state of life in the millennial era is full of challenges and competition. This has an impact, among others, on a high level of depression in addition to the availability of opportunities for those who have life competencies, and have multiliteracy that strengthens students' physical, mental, and intellectual capacities. For that we need a way how to shape the religious character of students, especially PAI students at the University of Muhammadiyah Gresik through digital literacy?. There needs to be a method in reviewing the research in revealing the existing problems, namely by using a descriptive method with a qualitative approach, focusing on the study of the formation of religious character of PAI UMG students. The results of the study reveal that various forms of collaboration and cooperation between communities and educational units outside the campus are indispensable in strengthening religious character education. There are various forms of collaboration that can be done in the context of developing character education for PAI UMG students in facing the millennial era, namely with Islamic digital literacy activists. Such as good attitudes and intentions, namely getting used to literacy through cellphone media (HP): speaking and writing in Short Message Service (SMS) or WhatsApp (WA) that is polite when communicating, behaves well, protects the environment, and looks after the environment. order.
\end{abstract}

Keywords: digital literacy, religious character, millennial generation, Islamic religious education

\section{Pendahuluan}

Perkembangan dunia kini tengah memasuki era millenial atau revolusi industri 4.0 dunia ke-empat dimana teknologi informasi telah menjadi basis dalam kehidupan manusia. Menyiapkan lulusan yang berkualitas dan mampu bersaing secara global, dan menguasai perkembangan teknologi merupakan hal yang penting untuk semua orang dan penting bagi masa depan suatu negara (Richard W. Bulliet.1994. p.154).

Dengan demikian, dukungan dan peran pendidikan diharapkan dapat meningkatkan daya saing bangsa di tengah persaingan global pesatnya perkembangan teknologi informasi. Gelombang besar dunia digital saat ini tak terbendung lagi, yang menghantarkan siapapun yang dapat memanfaatkannya dengan baik namun tak jarang 
dapat menghancurkan martabat seseorang dengan berbagai cara (Ahmad Rafiq. 2018. P.174). Ketidak pahaman manusia pada dunia digital membuat berbagai penyalahgunaan media digital terjadi di level personal, sosial dan nasional. Oleh karena itu, peningkatan kualitas pembelajaran merupakan salah satu tantangan bagi para pelaku pendidikan di Indonesia.

Ahmad juga berpendapat bahwa pendidikan merupakan upaya pengembangan potensi manusiawi dari para peserta didik, baik berupa fisik dan cipta maupun karsa agar potensi tersebut menjadi nyata dan dapat berfungsi bagi perjalan kehidupan (Ahmad Rafiq. 2018. P.175).

Dalam Peraturan Menteri Pendidikan dan Kebudayaan Nomor 16 Tahun 2014 Tentang Pemberlakuan Kurikulum Tahun 2006 dan Kurikulum 2013 maka terjadi perubahan dalam sistem pengajaran dan pembelajaran di Sekolah. Kurikulum yang dikembangkan berdasarkan prinsip bahwa peserta didik memiliki posisi sentral untuk mengembangkan kompetensinya supaya menjadi manusia yang beriman dan bertakwa kepada Tuhan Yang Maha Esa, berakhlak mulia, sehat dan berilmu, cakap, kreatif, mandiri dan menjadi warga negara yang demokratis serta bertanggung jawab.

Keadaan kehidupan pada era millenial ini sangat penuh tantangan dan persaingan. Hal ini sangat berdampak antara lain pada tingkat depresi yang tinggi disamping tersedianya peluang bagi yang memiliki kompetensi hidup, serta memiliki multiliterasi yang menguatkan kapasitas fisik, mental, serta intelektual peserta didik. Oleh karena itu, peserta didik dituntut harus memiliki karakter yang kuat agar dapat menghadapi tantangan abad 21 tersebut (Daryanto \& Karim. 2001. p.218).

Dalam Penguatan pendidikan karakter (PPK) peserta didik secara teknis harus dilaksanakan melalui PPK berbasis kelas dan berbasis budaya sekolah serta berbasis masyarakat. Diantara PPK berbasis kelas adalah pembelajaran tematik yang menggunakan kompetensi abad 21, dan yang paling utama mampu menjalankan 4C yaitu kemampuan critical thinking (berpikir kritis), creativity (kreativitas), collaboration (kolaborasi), dan communication (komunikasi) serta memiliki keterampilan berpikir tingkat tinggi (higher order thinking skills/HOTS). Sedangkan penguatan pendidikan karakter berbasis budaya adalah berupa kegiatan literasi.

Daryanto \& Karim juga berpendapat kegiatan literasi satuan pendidikan tidak dapat menutup kemungkinan berkolaborasi dengan lembaga, komunitas dan masyarakat lain diluar lingkungan kampus. Pelibatan publik dibutuhkan karena kampus tidak dapat 
melaksanakan visi dan misinya sendiri. Oleh karena itu berbagai macam bentuk kolaborasi dan kerjasama antar komunitas dan satuan pendidikan diluar kampus sangat diperlukan dalam penguatan pendidikan karakter (Daryanto \& Karim. 2001. p.259). Ada berbagai bentuk kolaborasi yang dapat dilakukan dalam rangka pengembangan pendidikan karakter mahasiswa PAI UMG dalam menghadapi era millenial yaitu kolaborasi dengan organisasi lain-organisasi lain sebagai pegiat literasi digital.

Sebagaimana yang kita ketahui usaha itu dilakukan agar dapat mempercepat terwujudnya visi nasional yang telah ditetapkan pemerintah untuk memanfaatkan peluang pada era revolusi industri yang keempat. Beberapa visi pemerintah adalah ingin menjadikan Indonesia untuk masuk dalam 10 besar negara yang memiliki perekonomian terkuat di dunia di tahun 2030.

\section{Tinjauan Pustaka}

\section{Literasi Gigital}

Gilster mengemukakan bahwa literasi digital adalah kemampuan menggunakan teknologi dan informasi dari piranti digital secara efektif dan efisien dalam berbagai konteks seperti akademik, karir dan kehidupan sehari-hari. Pendapat Gilster tersebut seolah-olah menyederhanakan media digital yang sebenarnya yang terdiri dari berbagai bentuk informasi sekaligus seperti suara, tulisan dan gambar.

Bawden menawarkan pemahaman baru terhadap literasi digital yang berakar pada literasi komputer dan literasi informasi. Literasi komputer berkembang pada dekade 1980an pada saat komputer mikro semakin luas dipergunakan tidak saja dilingkungan bisnis tetapi juga pada masyarakat. Sedangkan literasi informasi menyebarluas pada dekade 1990an manakala informasi semakin mudah disusun, diakses, disebarluaskan melalui teknologi informasi berjejaring sosial (Bawden, D. 2001. p.218-259).

Shapiro dan Hughes mengemukakan bahwa literasi komputer terdiri dari beberapa literasi (a) Literasi alat merupakan kompetensi menggunakan piranti lunak dan keras. (b) Literasi sumber yang diartikan sebagai pemahaman tentang berbagai sumber bentuk, akses dan informasi. (c) Literasi social structural yang merupakan pemahaman mengenai cara produksi dan manfaat informasi secara sosial. (d) Literasi penelitian merupakan penggunaan teknologi informasi untuk penelitian dan pengetahuan. (e) Literasi penerbitan sebagai kemampuan untuk berkomunikasi dan menerbitkan informasi. (f) Literasi teknologi baru sebagai pemahaman mengenai perkembangan teknologi informasi. 
(g) Literasi kritis sebagai kemampuan untuk mengevaluasi manfaat teknologi baru (EshetAlkalai, Y. 2004. p.93-106).

Selanjutnya Shao \& Purpur, berpendapat bahwa Literasi informasi merupakan salah satu keterampilan berpikir tingkat tinggi (higher order thinking skills/HOTS) yang dibutuhkan untuk mengembangkan dan mendukung kesuksesan akademis, profesional dan pribadi. Membiasakan literasi informasi dalam pembelajaran dan mengembangkan keterampilan riset secara mandiri diperlukan bagi profesional dalam pemasaran. Bertolak dari paparan di atas, urgensi penguasaan akan perkembangan dan kemajuan teknologi yang relatif serta aktivitas riset merupakan bagian penting dari kebutuhan dasar bagi setiap individu dan mendukung kesuksesan dalam menjalani kehidupan melalui kegiatan riset (Feli Y Siauw. 2014. p.57).

Beberapa kajian di atas bahwa paradigma baru dalam pembelajaran pun mengalami pergeseran dari proses menyerap ilmu pengetahuan dengan cara mengikuti perintahperintah tenaga pengajar dan fokus hanya pada tes dan penilaian kognitif dengan peluang yang sangat terbatas serta waktu pembelajaran terpola transaksi kepada pembelajaran yang baru sebagai proses aktualisasi diri (self directing \& self determine) membangun tingkah laku serta menghargai diri sendiri dengan fokus pada belajar kepda kemandirian dan belajar bagaimana cara belajar yang baik serta belajar dari berbagai sumber yang tiada batas ruang, isi serta tempat dan waktu melalui jaringan komputer. Literasi komputer lebih banyak berdimensi keterampilan fisik seperti kemampuan mengunakan alat-alat dan mengetahui sumbersumber informasi. Sedangkan literasi informasi lebih cenderung ketrampilan mental untuk memahami dan memproduksi informasi baru.

\section{Karakter Religius}

Undang-Undang Sisdiknas No. 20 tahun 2003 menyatakan bahwa tujuan pendidikan nasional adalah mengembangkan potensi peserta didik untuk memiliki kecerdasan, kepribadian dan akhlak mulia. Tujuan pendidikan tersebut dibuat agar pendidikan itu tidak hanya membentuk insan Indonesia yang cerdas, namun juga berkepribadian atau lebih berkarakter. Sehingga nantinya akan melahirkan generasigenerasi bangsa yang unggul dan tumbuh berkembang dengan karakter yang bernafaskan nilai-nilai luhur bangsa serta agama. Pengertian karakter menurut Pusat Bahasa Depdiknas adalah bawaan, jiwa, hati, kepribadian, perilaku, budi pekerti, 
personalitas, sifat, tabiat, temperamen, dan watak. Sedangkan berkarakter adalah berkepribadian, berperilaku, berwatak, bertabiat, bersifat dan berbudi pekerti.

Ciri khas atau karakter mengacu kepada serangkaian tindakan berupa (a). Behavior (perilaku), (b). Attitudes (sikap), (c). Motivations (motivasi), (d). Skill (keterampilan). Karakter merupakan ciri khas yang dimiliki oleh seorang individu atau suatu benda. Karakter itu asli serta mengakar terhadap kepribadian individu ataupun suatu benda, yang menjadi pendorong bagi seseoarang atau benda dapat bertindak dan bersikap sekaligus berucap serta menanggapi segala sesuatu. Hal senada juga diungkapkan bahwa karakter memiliki esensi dan makna yang sama dengan pendidikan moral dan pendidikan akhlak. Tujuannya adalah untuk membentuk pribadi anak supaya menjadi manusia yang baik, warga masyarakat dan warga negara yang baik (Surya. 2013. p.39).

Syamsul Arifin, dalam tulisannya yang berjudul Pendidikan dan Keberagamaan di Era Millenial, bahwa pendidikan tak pelak rentan juga dengan disrupsi. Disrupsi seperti ditulis Rhenald Kasali dalam Disruption adalah membuat hal yang baru sehingga yang lama ketinggalan zaman (doing thing diferently so others will be obsolote), pendidikan akan tertinggal jika hanya mengulang hal yang lama dengan sedikit perbaikan (iterasi), dan tidak mau melakukan disruptive innovation. Sebab menyusul revolusi industri 4.0, masyarakat mulai mengalami pergeseran pula menjadi masyarakat atau society 5.0 yang ditandai dengan masyarakat dengan kecerdasan super (super smart society) (Syamsul Arifin. 2019. 9).

Fahruddin Faiz, berpendapat dalam tulisannya yang berjudul Generasi Millenial, Peradaban Digital dan Upaya Membangun Kesadaran Kritis-Etis, bahwa sejarah peradaban umat manusia menunjukkan bahwa bangsa yang maju tidak dibangun hanya dengan mengandalkan kekayaan alam yang melimpah dan jumlah penduduk yang banyak. Bangsa yang besar ditandai antara lain dengan masyarakatnya yang memiliki budaya literasi tinggi. Literasi dalam konteks ini bukan hanya masalah bagaimana suatu bangsa bebas dari buta aksara, melainkan juga bagaimana semua anak bangsa memiliki kecakapan hidup agar mampu bersaing dan bersanding dengan bangsa lain untuk menciptakan kesejahteraan dunia. Budaya literasi tinggi yang dimaksud dapat dilihat dalam kemampuan bangsa tersebut dalam berkolaborasi, berpikir kritis, kreatif, komunikatif sehingga dapat unggul dalam persaingan global (Faruddin Faiz. 2019. p.11).

Noor Amirudin dalam artikelnya yang berjudul Strengthening The Existence Of Islamic Religion Education In The Industrial Revolution Era 4.0 (Study of PAI FAI 
Curriculum Review of Muhammadiyah Gresik University), memasuki era disrupsi ini, pendidikan Islam dituntut untuk lebih peka terhadap gejala-gejala perubahan sosial masyarakat. Pendidikan Islam harus mau mendisrupsi diri jika ingin memperkuat eksistensinya. Bersikukuh dengan cara dan sistem lama dan menutup diri dari perkembangan dunia, akan semakin membuat pendidikan Islam kian terpuruk dan usang (obsolet). Maka dari itu, terdapat tiga hal yang harus diupayakan oleh pendidikan Islam, yaitu mengubah mindset lama yang terkungkung aturan birokratis, menjadi mindset disruptif (disruptive mindset) yang mengedepankan cara-cara yang korporatif. Pendidikan Islam juga harus melakukan self-driving agar mampu melakukan inovasi-inovasi sesuai dengan tuntutan era 4.0. Selain itu, pendidikan Islam juga harus melakukan reshape or create terhadap segenap aspek di dalamnya agar selalu kontekstual terhadap tuntutan dan perubahan (Noor Amirudin. 2019. p.57).

Selanjutnya karakter sebagai cara berpikir dan berperilaku yang menjadi ciri khas tiap individu untuk hidup dan bekerja sama, baik dalam lingkup keluarga, masyarakat, bangsa, maupun negara. Namun pendapat yang berbeda dinyatakan oleh Elkind bahwa pendidikan karakter ialah segala sesuatu yang dilakukan guru, yang dapat mempengaruhi karakter atau watak peserta didik. Seorang guru membantu membentuk watak peserta didik. Dalam hal ini mencakup keteladanan bagaimana perilaku atau tingkah laku guru, cara guru berbicara atau menyampaikan sebuah materi serta bagaimana guru bertoleransi dengan peserta didik dan berbagai hal yang terkait lainnya.

Sedangkan menurut Wiyani dalam Ahmad, ada enam pilar pendidikan berkarakter yaitu (a) Kepercayaan (Trustworthiness) mempunyai sikap jujur tidak menipu dan menjiplak atau mencuri serta handal dalam melakukan apa yang anda katakan, selalu keberanian dalam melakukan hal yang benar, bangun reputasi yang baik, patuh berdiri dengan keluarga, teman dan negara. (b) tanggungjawab (responsibility) dapat mengontor diri, selalu melakukan hal yang terbaik, berpikir sebelum melakukan tindakan, mempertimbangkan konsekuensi dan bertanggungjawab atas pilihan anda (c) Respek (Recpect) bersikap toleran terhadap segala perbedaan, gunakan sopan santun dan bukan bahasa yang buruk, pertimbangkan perasaan orang lain yang ada disekitar jangan mengancam dan memukul atau menyakiti orang lain, damaikanlah dengan kemarahan, hinaan dan perselisihan. (d) Keadilan (Fairness) bermain sesuai aturan, ambil seperlunya dan berbagi, berpikiran terbuka, mendengarkan orang lain, jangan mengambil keuntungan dari orang lain, jangan menyalahkan orang lain sembarangan. (e) Peduli (caring) 
bersikaplah penuh kasih sayang dan menunjukkan anda peduli, ungkapkan rasa syukur, maafkan orang lain, membantu orang yang membutuhkan. (f) Kewarganegaraan (Citizenship) menjadikan sekolah dan masyarakat menjadi lebih baik serta bekerja sama, melibatkan diri dalam segala urusan masyarakat, menjadi tetangga yang baik, mentaati hukum dan aturan serta menghormati otoritas, melindungi lingkungan hidup dimanapun berada. Siswa atau peserta didik dituntut untuk mampu menerapkan enam pilar tersebut dimanapun (Ahmad Rafiq. 2018. p.177-180).

\section{Generasi Milenial}

Untuk mengetahui siapakah generasi milenial diperlukan kajian literatur dari berbagai sumber yang merupakan pendapat beberapa peneliti berdasarkan rentang tahun kelahiran. Istilah milenial pertama kali dicetuskan oleh William Strauss dan Neil dalam bukunya yang berjudul Millennials Rising: The Next Great Generation (2000). Mereka menciptakan istilah ini tahun 1987, yaitu pada saat anak-anak yang lahir pada tahun 1982 masuk pra-sekolah. Saat itu media mulai menyebut sebagai kelompok yang terhubung ke milenium baru di saat lulus SMA di tahun 2000. Pendapat lain menurut Elwood Carlson dalam bukunya yang berjudul The Lucky Few: Between the Greatest Generation and the Baby Boom (2008), generasi milenial adalah mereka yang lahir dalam rentang tahun 1983 sampai dengan 2001. Jika didasarkan pada Generation Theory yang dicetuskan oleh Karl Mannheim pada tahun 1923, generasi milenial adalah generasi yang lahir pada rasio tahun 1980 sampai dengan 2000. Generasi milenial juga disebut sebagai generasi Y. Istilah ini mulai dikenal dan dipakai pada editorial koran besar Amerika Serikat pada Agustus 1993.

Putra dalam kajiannya tentang teori perbedaan generasi menyajikan pengelompokan generasi (salah satunya adalah generasi milenial) dari beberapa pendapat peneliti yang berasal dari berbagai negara. Beberapa pendapat tentang perbedaan generasi tersebut disajikan dalam tabel berikut ini.

Tabel 1. Pengelompokan Generasi (Yanuar Surya Putra. 2016)

\begin{tabular}{|c|c|c|c|c|c|}
\hline Sumber & \multicolumn{5}{|c|}{ Label } \\
\hline Tapscott (1988) & - & $\begin{array}{c}\text { Baby Boom } \\
\text { Generation } \\
(1946-1964)\end{array}$ & $\begin{array}{c}\text { Generation X } \\
(1965-1975)\end{array}$ & $\begin{array}{c}\text { Digital Generation } \\
(1976-2000)\end{array}$ & - \\
\hline pwe \& Strauss (2000) & $\begin{array}{c}\text { Silent } \\
\text { Generation } \\
(1925-1943\end{array}$ & $\begin{array}{c}\text { Boom } \\
\text { Generation } \\
(1943-1960)\end{array}$ & $\begin{array}{c}\text { 13th Generation } \\
(1961-1981)\end{array}$ & $\begin{array}{c}\text { Millineal } \\
\text { Generation (1982- } \\
2000)\end{array}$ & - \\
\hline $\begin{array}{c}\text { Zemke et al } \\
\text { (2000) }\end{array}$ & $\begin{array}{c}\text { Veterans } \\
(1922-1943)\end{array}$ & $\begin{array}{c}\text { Baby Boomers } \\
(1943-1960)\end{array}$ & $\begin{array}{c}\text { Gen-Xers } \\
(1960-1980)\end{array}$ & $\begin{array}{c}\text { Nexters (1980- } \\
2000)\end{array}$ & - \\
\hline Lancaster \& & $\begin{array}{c}\text { Traditionalist } \\
\text { (1900-1945) }\end{array}$ & $\begin{array}{c}\text { Baby Boomers } \\
(1946-1964)\end{array}$ & $\begin{array}{c}\text { Generation } \\
\text { Xers }\end{array}$ & Generation Y & - \\
Stillman (2000) & \multicolumn{5}{|c|}{} \\
\hline
\end{tabular}




\begin{tabular}{|c|c|c|c|c|c|}
\hline $\begin{array}{c}\text { Martin \& Tulgan } \\
(2002)\end{array}$ & $\begin{array}{c}\text { Silent } \\
\text { Generation } \\
(1925-1942)\end{array}$ & $\begin{array}{c}\text { Baby } \\
\text { Boomers } \\
(1946-1964)\end{array}$ & $\begin{array}{c}\text { Generations X } \\
(1965-1977)\end{array}$ & $\begin{array}{c}\text { Millinials (9181- } \\
1999)\end{array}$ & - \\
\hline $\begin{array}{c}\text { Oblinger \& } \\
\text { Oblinger (2005) }\end{array}$ & $\begin{array}{c}\text { Maataures } \\
(<1946)\end{array}$ & $\begin{array}{c}\text { Baby } \\
\text { Boomers }\end{array}$ & $\begin{array}{c}\text { Generation } \\
\text { Xers (1965- } \\
1 \text { 1947-1964) }\end{array}$ & $\begin{array}{c}\text { Gen-Y/NetGen } \\
(1981-1995)\end{array}$ & $\begin{array}{c}\text { Post } \\
\text { Millinials } \\
(1955- \\
\text { present })\end{array}$ \\
\hline
\end{tabular}

Tabel di atas ada 6 pendapat tentang generasi milienial yang dilihat dari rentang waktu kelahiran. Penyebutan istilah generasi milenial juga berbeda antar peneliti. Tapscott (1998) menyebut generasi milenial dengan istilah Digital Generation yang lahir antara tahun 1976- 2000. Kemudian Zemke et al (2000) menyebut generasi milenial dengan istilah Nexters yang lahir tahun 1980-1999. Oblinger (2005) menyebut generasi milenial dengan istilah Generasi Y/NetGen, lahir antara 1981- 1995. Terakhir Howe dan Strauss, Lancaster dan Stillman (2002), serta Martin dan Tulgan (2002) menyebut dengan istilah Generasi Milenial/Generasi Y/Milenial yang dikenal sampai sekarang, meskipun rentang tahun kelahirannya masing-masing berbeda. Masih di dalam makalah yang sama, Putra menambahkan hasil penelitian Benesik, Csikos, dan Juhes (2016).

\section{Metode Penelitian}

\section{Pendekatan dan Jenis Penelitian}

Tujuan penelitian ini adalah untuk mendapatkan gambaran mendalam yang didasarkan dari fakta-fakta yang ada di lapangan tentang literasi digital dalam membentuk karakter religius generasi milenial (studi tentang pembentukan karakter mahasiswa PAI universitas muhammadiyah gresik). Oleh karena itu peneliti menggunakan landasan dasar atau paradigma interpretif.

Pendekatan yang peneliti gunakan adalah kualitatif dengan pertimbangan, penelitian kualitatif lahir bertujuan untuk menangkap arti atau memahami gejala, peristiwa, fakta, kejadian, realitas atau masalah tertentu mengenai peristiwa social dan kemanusiaan dengan kompleksitas secara mendalam (Mudjia Rahardjo. 2022). Jenis penelitian yang peneliti gunakan dalam kajian ini adalah studi kasus dengan rancangan kasus tunggal.

\section{Kehadiran Penelitian}

Penelitian kualitatif ini, peneliti hadir di lapangan untuk melakukan pengamatan, karena peneliti merup[akan instrument penelitian utama yang memang harus hadir sendiri secara langsung di lapangan untuk mengumpulkan data. Kedudukan peneliti dalam 
penelitian ini berperan sangat komplek yaitu sebagai perencana, pelaksana pengumpulan data, analisis, penafsir data dan pada akhirnya peneliti menjadi pelapor hasil penelitian yang dilakukan.

\section{Lokasi Penelitian}

Penelitian ini difokuskan di Universitas Muhammadiyah Gresik (UMG) yang beralamatkan di Jalan Sumatera 101 Gresik Kota Baru (GKB) Randuagung Kebomas Gresik 61121. Lokus tersebut sangan strategis bagi peneliti, disamping itu peneliti juga sebagai Dosen Tetap yang dapat memberikan kemudahan dalam melakukan penelitian tersebut.

\section{Data dan Sumber Data}

Data dalam metode penelitian kualitatif adalah apa yang dikatakan oleh orangorang yang berkaitan dengan seperangkat pertanyaan yang diajukan oleh peneliti (Rusman Ahdi. 2005. 63). Data yang telah dikumpulkan dalam penelitian ini adalah data yang sesuai dengan focus penelitian yaitu tentang literasi digital dalam membentuk karakter religius generasi milenial (studi tentang pembentukan karakter mahasiswa PAI universitas muhammadiyah gresik).

Jenis data dalam penelitian ini dibedakan menjadi dua, yaitu data primer dan data sekunder. Data primer diperoleh dalam bentuk-bentuk kata-kata atau ucapan lisan (verbal) dan perilaku dari informan terkait dengan filosofi dan pelaksanaan literasi digital dalam membentuk karakter religius generasi milenial (studi tentang pembentukan karakter mahasiswa PAI universitas muhammadiyah gresik). Sedangkan data sekunder diperoleh dari dokumen-dokumen, foto, benda-benda yang dapat digunakan sebagai pelengkap data primer. Suharsimi Arikuntomengungkapkan, bahwa sumber data merupakan subjek dari mana data tersebut diperoleh. Sumber data dalam penelitian ini harus ditentukan dengan baik, karena data tidak akan diperoleh tanpa adanya sumber data (Suharsimi Arikunto. 2022. p.107).

\section{Teknik Pengumpulan Data}

Dalam rangka mendapatkan data yang utuh dan menyeluruh, maka dalam pengumpulan data penelitian digunakan tiga Teknik, yaitu: wawancara mendalam (in depth interview), observasi partisipan (participant observation), studi dokumentasi (study of documentasi). Tiga Teknik pengumpulan data tersebut merupakan Teknik dasar dalam penelitian kualitatif yang disepakati oleh sebagaian besar penulis (Nasution S. 1988. p.55). 


\section{Teknik Analisis Data}

Dengan mengandalkan peneliti sebagai instrument penelitian, maka analisis data telah dilakukan di lapangan dengan tujuan agar tidak berubah dalam menginterpretasikan data maupun setelah data terkumpulkan. Analisis data merupakan proses mencari dan mengatur secara sistematis hasil wawancara mendalam, observasi partisipan, dan dokumentasi yang dihimpun oleh peneliti, sehingga meningkatkan pemahaman bagi peneliti tentang focus penelitian dan sekaligus menyajikan hasil penelitian tersebut sebagai temuan baru bagi orang lain.

Menurut Patton, teknik analisis data adalah proses urutan mengatur data, mengorganisasikannya ke dalam suatu pola, kategori dan satu uraian dasar. Untuk dapat mengatur sambil mengahasilkan uraian dasar dipergunakan metode analisis sesuai dengan ciri pendekatan kualitatif, teknik analisa data dilakukan sejak awal, dan dikembangkan selama proses pengumpulan data sampai proses penyusunan laporan (Moleong. L. J. 2005. p.184).

Proses analisis data, peneliti mengklasifikasikan data menurut temanya, kemudian dipilah-pilah. Data yang diperlukan dikategorikan menjadi beberapa tema utama untuk menjawab pertanyaan-pertanyaan penelitian yang yang telah ditetapkan dan analisis secara deskriptif. Sedangkan data yang kurang relevan dengan pertanyaan-pertanyaan tersebut disimpan. Setelah itu dicoba menginterpretasikan melalui tiga alur kegiatan yang berlangsung secara bersamaan, yaitu reduksi data, penyajian data dan verifikasi (B. Miles \& M. Huberman. 1992. p.87). Pada langkah reduksi, peneliti memilih dan menyederhanakan data dari catatan lapangan. Catatan lapangan yang banyak disederhanakan, disingkat, dirangkum dan dipilih sesuai dengan permasalahan yang telah ditetapkan. Proses reduksi data ini, penulis melakukan pengulangan untuk menghindari terjadinya kekeliruan, hanya data yang berkaitan dengan pokok permasalahan saja yang dipilih, sedangkan yang lain dikeluarkan dari proses analisis. Adapun dalam proses penyajian data, data yang telah penulis pilih melalui reduksi, pemulis sajikan dalam bentuk tulisan atau kata-kata yang sistematis, sehingga mudah untuk disimpulkan. Selanjutnya penarikan kesimpulan yang penulis lakukan selama proses penelitian berlangsung.

\section{Hasil Dan Pembahasan}


Penguatan pendidikan karakter mahasiswa secara teknis harus dilaksanakan melalui berbasis kelas dan berbasis literasi budaya kampus serta berbasis masyarakat. Diantara penguatan pendidikan karakter berbasis budaya kampus adalah kompetensi abad 21, dan yang paling utama mampu menjalankan 4C yaitu kemampuan critical thinking (berpikir kritis), creativity (kreativitas), collaboration (kolaborasi), dan communication (komunikasi) serta memiliki keterampilan berpikir tingkat tinggi (higher order thinking skills/HOTS) (Kailani, dkk 2018. p.3). Sedangkan penguatan pendidikan karakter berbasis budaya kampus adalah berupa kegiatan literasi.

Pemahaman baru terhadap literasi digital yang berakar pada literasi komputer dan literasi informasi. Literasi komputer berkembang pada dekade 1980an pada saat komputer mikro semakin luas dipergunakan tidak saja dilingkungan bisnis tetapi juga pada masyarakat. Sedangkan literasi informasi menyebarluas pada dekade 1990an manakala informasi semakin mudah disusun, diakses, disebarluaskan melalui teknologi informasi berjejaring sosial.

Beberapa konsep pendidikan adab 21 yang telah diadaptasi oleh Kemenag Republik Indonesia untuk dapat mengembangkan kurikulum dari tingkat Sekolah Dasar (SD), selanjutnya Sekolah Menengah Pertama (SMP), kemudian Sekolah Menengah Atas (SMA), sampai perguruan tinggi antara lain. a) keterampilan abad 21 (21st century skills). b) pendekatan ilmiah (scientific approach). c) pembelajaran otentik dan penilaian otentik (authentic learning \& authentic assesment). Selanjutnya dari beberapa konsep tersebut disesuaikan untuk mengembangkan pendidikan menuju Indonesia lebih kreatif pada 2045. Terobosan penting ini hendaknya melibatkan semua pemangku kepentingan di bidang pendidikan, mulai dari tingkat pusat, provinsi, kabupaten/ kota, hingga satuan pendidikan. Pelibatan orang tua peserta didik dan masyarakat juga menjadi komponen penting dalam Gerakan Literasi Sekolah.

Literasi digital tidak akan mampu berjalan dengan optimal mungkin jika hanya berpijak pada kemampuan dalam membaca dan menulis serta bagaimana menggunakan medsos khususnya media digital. Melainkan harus dibarengi dengan karakter yang baik dan kuat dalam menjaga tingkah laku dalam berkomunikasi di media digital itu sendiri. Khususnya pada media sosial, dimana masyrakatnya sangatlah beragam yang mempunyai latar belakang yang berbeda.

Disitulah pentingnya karakter tersebut pada penguatan literasi digital. Ibarat seorang driver yang menggerakan kemmapuan dalam literasi digital ini. Di samping itu, 
hal ini akan menjadi jiwa atau nalar dalam literasi digital itu sendiri. Tanpa karakter yang baik dan kuat (religious), literasi digital tidak akan mampu berjalan dengan baik. Seberapa hebatpun kemampuan membaca dan menulis serta penggunaan media digitalnya. Pasti tidak akan mampu bijak dalam menggunakannya (Kurnia, N., \& Astuti, S. I. 2017. P.149.).

Hanya ada satu jalan dalam menumbuhkan literasi digital dalam membentuk karakter religius yaitu melalui pendidikan karakter religius sendiri. Pendidikan karakter bisa ditumbuhkan di setiap lingkungan di manapun individu tersebut melakukan proses sosialisai. Hal ini sudah terjadi di lingkungan mahasiswa PAI UMG. Subianto (Subianto. 2013. p..331), bahkan di dunia digitalpun semestinya pendidikan karakter ini bisa ditumbuhkan dengan baik. Pendidikan karakter di perkuliahan selama ini telah berlangsung dengan sistem yang sangat baik. Hal ini bisa dilihat dari adanya pendidikan karakter secara menyeluruh, seperti masuknya pendidikan karakter dalam setiap capaian pembelajaran yang direalisasikan dengan pengajaran di kelas. Termasuk juga pendidikan karakter di luar kelas serta kegiatan ektrakurikuler (Kurniawan. 2015. p.41).

Pendidikan karakter di rumah atau lingkungan keluarga memang masih belum optimal. Beberapa orang tua masih acuh terhadap pentingnya pendidikan karakter ini. Padahal sesungguhnya pendidikan karakter di lingkungan keluarga inilah yang sangat baik dan mempunyai peran yang kuat terhadap karakter anak. Memang harus dibiasakan pendidikan karakter ini, dibiasakan dalam litersi rutinitas sehari-hari berupa tindakan melalui tulisan yang biasa dilakukan melalui media hendpon (HP): bertutur kata dan menulis dalam Short Message Service (SMS) atau WhatsApp (WA) yang sopan saat komunikasi, bertingkang laku yang baik, menjaga ingkungan, dan menjaga ketertiban.

Pendidikan karakter sebagaimana di atas sebetulnya telah diatur oleh normanorma yang berlaku di masyarakat serta didukung oleh budaya khas yang banyak berisi aktivitas-aktivitas kebudayaan dan kearifan lokal yang membiasakan setiap individu untuk terbiasa melakukan aktivitas tersebut yang sarat akan nilai yang religius. Nilai religius yang diajarakan secara turun temurun sehingga mampu melekat di setiap hati individu. Nilai religus tersebut tentunya berisi nilai-nilai pendidikan karakter yang nantinya mampu menguatkan setiap individu tersebut.

\section{Kesimpulan}


Kemajuan IPTEK seperti saat ini, akses informasi yang sangat mudah di dapat seharusnya membuat mahasiswa PAI UMG semakin cerdas dalam memandang dan menanggapi sebuah permasalahan. Literasi digital merupakan sebuah kemampuan yang wajib dimiliki setiap pengguna media digital agar lebih bijak dalam berkomunikasi dan bertingkah laku di dunia digital itu sendiri. Di samping itu, perlu juga penguatan pendidikan karakter dalam berinteraksi di dunia digital. Bagaimanapun literasi digital haruslah didukung dengan sebuah sikap dan niat yang baik, yaitu melalui pendidikan karakter religius sendiri, yaitu membiasakan dalam literasi dilakukan melalui media hendpon (HP): bertutur kata dan menulis dalam Short Message Service (SMS) atau WhatsApp (WA) yang sopan saat komunikasi, bertingkang laku yang baik, menjaga ingkungan, dan menjaga ketertiban.

\section{Daftar Pustaka}

Ahdi, Rusman. 2005. Memahami Metodologi Penelitian Kualitatif. Malang: UIN Press Amirudin, Noor. 2019. Strengthening The Existence Of Islamic Religion Education In The Industrial Revolution Era 4.0 (Study of PAI FAI Curriculum Review of Muhammadiyah Gresik University). Jurnal TAMADDUN: Jurnal Pendidikan dan Pemikiran Keagamaan, XX (1), Januari

Arifin, Syamsul. 2019. Pendidikan dan Keberagamaan di Era Milenial. Materi Seminar

Nasional yang diselenggarakan Program Studi Pendidikan Agama Islam Fakultas Agama Islam Universitas Muhammadiyah Gresik

Arikunto, Suharsimi. 2022. Prosedur Penelitian Suatu Pendekatan Praktek. Jakarta: Rineka Cipta

Bawden, D. 2001. Information and Digital Literacy: a review of concept. Journal of Dokementation, 57(2), 218-259 Tibor Koltay. The Media and the Literacy: Media Literacy, Information Literacy and Digital Literacy.

Bulliet, Richard W. 1994. Islam the View from the Edge. New York: Columbia University Press.

Daryanto \& Karim. 2001. Information and Digital Literacy: a review of concept, Journal of Dokementation, 57 (2)

Eshet-Alkalai, Y. 2004. Digital Literacy: A Conceptual Framework for Survival Skills in the Digital Era. Journal of Educational Multimedia and Hypermedia, 13(1) 
Noor Amirudin

Faiz, Fahruddin. 2019. Generasi Milenial, Peradaban Digital dan Upaya Membangun Kesadaran Kritis-Etis. Materi Seminar Nasional yang diselenggarakan Program Studi Pendidikan Agama Islam Fakultas Agama Islam Universitas Muhammadiyah Gresik

Hasan, Noorhaidi. 2018. Literatur Keislaman Generasi Milenial: Transmisi, Apropriasi, dan Kontestasi. Yogyakarta: Pascasarjana UIN Sunan Kalijaha Press

Kurnia, N., \& Astuti, S. I. 2017. Peta Gerakan Literasi Digital Di Indonesia: Studi Tentang Pelaku, Ragam Kegiatan. Kelompok Sasaran Dan Mitra Yang Dilakukan Oleh Japelidi. Informasi, 47(2)

Kurniawan. 2015. Tri Pusat Pendidikan Sebagai Sarana Pendidikan Karakter Anak Sekolah Dasar. PEDAGOGIA: Jurnal Pendidikan, 4(1)

Miles \& M. Huberman. 1992. Analisis Data Kualitatif Buku Sumber tentang MetodeMetode Baru. Jakarta: UIP

Moleong, Lexi. J. 2005. Metodologi Penelitian Kualitatif. Bandung: Remaja Rosdakarya

Nasution, S. 1988. Metode Penelitian Naturalistik-Kualitatif. Bandung: Tarsito

Putra, Yanuar Surya. 2016. Teori Perbedaan Generasi. Journal Theoritical Review

Rafiq, Ahmad. 2018. Dinamika Literatur Islamis di Ranah Lokal dalam Literatur Keislaman Generasi Milenial: Tranmisi, Apropriasi, dan Kontentasi. Yogyakarta: Pascasarjana UIN Sunan Kalijaga Press

Siauw, Feli Y. 2014. Beyond the Inspiration. Jakarta: Alfatih Press

Subianto. 2013. Peran Keluarga, Sekolah, Dan Masyarakat Dalam Pembentukan Karakter Berkualitas. Edukasia: Jurnal Penelitian Pendidikan Islam, 8(2)

Surya. 2013. Gue Farmasis Muda. Banjarbaru: Zukzez express 